\title{
The Coverage of Crises News in the Malaysian and Nigerian Newspapers between 2007 and 2009
}

\author{
S. C. Ihediwa and Md. S. A. Ishak
}

\begin{abstract}
The reporting of crisis anywhere in the world has certain elements in common with the reporting of other events. In this paper, it is used as a definer for political, economic, health and environmental crises. Crisis reporting could be defined as the reporting of information about the state of affairs in which a decisive change for the worse is about to, or has occurred. Newspapers have a unique and exceptionally important role to play in covering national crises. Accurate and appropriate information about a crisis is an expectation that is required if the government wants to remove fears from the public. This is because modern democracy depends on a vibrant news media to keep the public informed. Newspaper has had a long history of information dissemination, particularly in its in-depth reporting of events. This task becomes more demanding in this age of the internet, which has brought with it so much competition for the printed copy. This is a comparative study on how Malaysian and Nigerian newspapers reported some of the crises the two countries experienced between 2007 and 2009. Through content analysis, the study compared the coverage of crises by newspapers in the two countries. This is aimed at determining how newspapers in the two countries differed in their reporting. The research relied on the framing theory. One of the findings is that Nigerian newspapers have significantly reported more political, economic and environmental crises while Malaysian newspapers have reported more health crisis.
\end{abstract}

Index Terms-Crisis, newspapers, reporting, coverage.

\section{INTRODUCTION}

Malaysia and Nigeria are two developing countries formerly under British colony, and with a press that is modeled after the British press. This common colonial history is one of the reasons that informed this study. As countries across the globe experience crises now and then, Malaysia and Nigeria are not spared as each of them has at one time or the other experienced crisis as the case may be in this study. Moreover, it should be pointed out that the reporting of crises in the two countries and anywhere in the world has certain elements in common with the reporting of other events. In the past two decades, the world has been stunned by the increase in number of crises. During crisis situation, the mass media becomes an important vehicle that provides the public with information about the situation. Newspapers in Malaysia and Nigeria are usually sought for by people to get in-depth news regarding crisis events. This is regardless of the fact that internet and the online media

Manuscript received August 9, 2013; revised December 25, 2013.

The authors are with the Department of Media Studies, Faculty of Arts and Social Science, University of Malaya, 50603 Kuala Lumpur Malaysia (e-mail: Chibundu@siswa.um.edu.my, ihediwa@utar.edu.my, Mdsidin.um.edu.my). compete with the mainstream newspapers for news. It is more so because of its accessibility and cheap nature as a medium of mass communication. During crisis people need access to accurate information, and gather clear and specific instructions to help them act appropriately. Without access to information, members of the public will remain helpless and clueless and will not know what to do to control the situation. This is because generally countries experience crisis as overwhelming, leaving them without means to cope or to adjust. Sometimes, they cannot make sense of what is happening or why it is happening. Under this situation they become bereft of means for exercising some form of control on their lives. Besides, conflicting interests arise sometimes as the media pursue to tell everything while the government seeks to control the public from panicking. These conflicting interests could be the authorities who may respond either as denial or apologia covers up or giving out information selectively or wholly. Another point of view is that of the audience. The audience could be sceptical or believe the information concerning the situation. On the other hand, the media could be the critical media, complaint media or straight reporting. Chandler, Wallace and Scott noted that ccommunication challenges are exacerbated during a crisis when time is short, decisions are urgent, information limited, and the opportunities for the rich interaction people require are constrained [1]. This shows that pressure is greater during a crisis, and the way the information is communicated can go a long way in helping people make informed decisions.

\section{OBJECTIVES AND SignificAnCE OF STUdy}

The objective of this study is to compare the coverage of political, economic, health and environmental crises by the Malaysian and Nigerian newspapers. By comparing the two countries, the study will find out the rate of coverage, the difference in the coverage, the sources of information and the frames used in the reporting. To help achieve these objectives, some research questions are stated and these include the following:

1) What is the rate of coverage given to these crises in the two countries?

2) Is there any difference in the way the crises were reported by newspapers in the two countries?

3) Who are the sources of information for the stories?

4) Which frame featured more prominently in each of the four newspapers?

Besides, the hypothesis for the study is that there is difference between newspapers in the two countries regarding their coverage of the different crises.

The findings of this study provide a useful insight into the 
way and manner newspapers in the two countries cover political, economic, health and environmental crises. However, there are no existing literatures on comparative study between Malaysia and Nigeria in the coverage of these crises. However, literatures exist in each of the two countries regarding the different types of crisis that each experiences. This study in a way will help to fill the knowledge gap that exists in determining how the press in the two countries compare and contrast with each other in reporting crises. Again, the findings will deepen readers understanding of the media environment in the two countries and how the mainstream government-owned newspapers determine what constitutes crisis.

\section{THEORETICAL FRAMEWORK}

Reference [2] said that the press has an acknowledged role in reporting news, but its role as described in framing goes beyond that. Through headlines the press captures peoples' attention, and through the process of framing it links events and situations with other concepts and events. Attaching the word "Crisis" to an event adds to its news value, creates attention and can be a call to action. Investigating situations which the media predicts will lead to future crisis increases the role of the press in influencing future action, and it demonstrates the benefits of the press as an early warning system of the inadequate systems of governance and management and control over preventable crises to which it draws attention. Journalists may employ many different frames in their coverage of an issue, and scholars agree that this abundance in choice in how to tell and construct stories can be captured in analyses as certain distinctive characteristics. Weaver mentioned that frames can be studied by means of systematic content analysis or more interpretative textual analysis alone [3]. Van Gorp also observed that some researchers opt for a rather qualitative approach in analyzing media frame, such as discourse analysis, while others apply traditional content analysis or other quantitative methods [4]. He argued that the strongly abstract nature of frames implies that quantitative research methods should be combined with the interpretative prospects of qualitative methods. Situating this argument in this study, it is one of the reasons that informed the use of a combination of quantitative and qualitative approaches in extracting information. Furthermore, Tankard remarked that framing might give quantitative researchers a way to approach ideology, a subject mostly dealt with by critical theorists to date [5].

Acco Reference [6] stated that in recent years framing theory has taken over from agenda setting and cultivation theory as the most commonly applied research approach in the field of communication science. It should be noted however that one of the most pressing issues in framing research is the lack of conceptual clarity and operational definitions. But one can draw from Entman who suggests that to frame is to "select some aspects of a perceived reality and make them more salient in a communicating context [7].

Reference [8] argued that thematic units may be the most useful classification system used for categorizing in content analysis. Moreover, he pointed out that a particularly promising approach to thematic analysis developed during the past few decades is the concept of framing. Since researchers are looking for commonly used frames that reflect the variables shaping content, Riffe, Lacy and Fico equally argued that framing analysis should reveal common, typical or repeated structure [9]. Furthermore, they stated that this structure relates to variables such as news routines, ideology and economic resources that lead to commonly used frames that are applied consistently across media and across time. In addition, they highlighted that the nature of this structure and the units attached to it continues to develop. Therefore, future work should yield a theory or theories relating antecedents to frames in content and the frames to media effects.

\section{Methodology}

The study used a combination of quantitative and qualitative methods to generate data. The crises news stories retrieved from the four newspapers for the period under study (2007 and 2009) were content-analyzed to find out the rate of coverage of these crises in the two countries. The four newspapers are the New Straits Times, and the Star (Malaysia), the Sun and the Nation (Nigeria). This is to help determine how newspapers in the two countries have compared in their respective reporting of the crisis issues. On the other hand, by applying qualitative method, the study used the interview technique to obtain information from journalists from the four newspapers. Such information is to know their perception towards crisis reporting, degree of freedom of the press in each of the countries, ownership and control of the media and the skills of the journalists in crisis reporting. The time frame for the research is from January 1, 2007 to December 31, 2009. The criteria for extracting the stories include type of crisis, headline given to the story, where and when the crisis occurred. Others are causes of the crisis, categories of the news and the page numbers where the crises are reported. In all, a total of 2,834 news stories were collected from the four newspapers, 912 from Malaysian newspapers and 1922 from Nigerian newspapers. Each of the stories serves as unit of analysis. Pearson Chi-Square test was used to determine the aggregate reporting of the crises by the four newspapers. Again each type of the crisis was further analyzed to find out how Malaysia newspapers differ from Nigerian newspapers in their reporting. In terms of content analyzing framing in the news, this study used the deductive approach, using existing news frames to verify whether they occur in the news [10]. Several previous studies have already found the dominant news frames that characterize crisis. For example, reference [11] discussed comprehensively several different types of frames dominantly used in the U.S. news coverage. These are conflict, economic consequences, human impact, and morality. Based on these frames, Semetko and Valkenburg analyzed five national newspapers and five national television news stories in the period surrounding the Amsterdam meeting of European heads of state in 1997 and identified five news frames, namely, conflict, human interest, economic consequence, morality, and attribution of responsibility. The found out that the most dominant frame used in the news was attribution of responsibility, followed 
by conflict, economic, human interest and morality. In view of the above, this study will apply these five different types of frames to know which one featured prominently more than others in newspapers in the two countries.

\section{FINDINGS}

Table I above shows the aggregate reporting of the different types of crisis in the four newspapers from 2007 to 2009. It shows that Malaysian newspapers (New Straits Times and the Star) reported a total of 269 political crisis stories, 111 economic crisis stories, 368 health crisis stories and 164 environmental crisis stories. On the other hand, the Nigerian newspapers (the Sun and the Nation) recorded a total of 837 political crisis news, 287 economic crisis news,
131 health crisis and 665 environmental crisis stories.

TABLE I: SUMMARY OF AGGREGATE REPORTING OF THE CRISES BY THE FOURS NEWSPAPERS.

\begin{tabular}{|l|l|l|}
\hline Types of crisis & $\begin{array}{l}\text { Malaysian newspapers. } \\
\text { (New Straits Times and } \\
\text { the Star) }\end{array}$ & $\begin{array}{l}\text { Nigerian newspapers } \\
\text { (the Sun and the } \\
\text { Nation) }\end{array}$ \\
\hline Political crisis & 269 & 837 \\
Economic crisis & 111 & 287 \\
Health crisis & 368 & 131 \\
Environmental crisis & 164 & 665 \\
\hline Total & $\mathbf{9 1 2}$ & $\mathbf{1 9 2 0}$ \\
\hline
\end{tabular}

TABLE II: CHI-SQUARE TEST SHOWING AgGREgATE REPORTING OF THE CRISES By NEWSPAPERS IN MALAYSIA AND NIGERIA.

\begin{tabular}{|c|c|c|c|c|c|}
\hline & $\begin{array}{l}\text { Political crisis reports in } \\
\text { the newspapers }\end{array}$ & $\begin{array}{l}\text { Economic crisis reports } \\
\text { in the newspapers }\end{array}$ & $\begin{array}{l}\text { Health crisis reports in } \\
\text { the newspapers }\end{array}$ & $\begin{array}{l}\text { Environmental crisis reports } \\
\text { in the newspapers }\end{array}$ & $\begin{array}{l}\text { Overall comparison of } \\
\text { crisis reporting } \\
\text { (Nigeria/Malaysia) }\end{array}$ \\
\hline Chi-Square & $291.703^{a}$ & $79.210^{b}$ & $112.563^{c}$ & $302.776^{d}$ & $359.951^{e}$ \\
\hline df & 1 & 1 & 1 & 1 & 1 \\
\hline Asymp. Sig. & 0.000 & 0.000 & 0.000 & 0.000 & 0.000 \\
\hline
\end{tabular}

Table II above shows that there is significant difference in the overall coverage of crises news in the two countries. Generally, Nigerian newspapers have significantly reported more crises news than their Malaysian counterparts, $X^{2}(1, n$ $=2,834)=359.951, P<0.001$.

On different types of crisis, the two countries were compared, and the results show that:

Nigerian newspapers have significantly reported more political crisis than Malaysian newspapers, $X^{2}(1, n=1106)=$ 291.703, $P<0.001$.

Nigerian newspapers have significantly reported more economic crisis than the Malaysian newspapers, $X^{2}(1, n=$ 400) $=79.210, P<0.001$.

Nigerian newspapers have significantly reported more environmental crisis than their Malaysian counterparts, $X 2$ (1, $n=829)=302.776, P<0.001$.

Malaysian newspapers have significantly reported more health crisis than their Nigerian counterparts, $X^{2}(1, n=499)$ $=112.563, P<0.001$.

TABLE III: SOURCES OF NEWS IN THE FOUR NEWSPAPERS

\begin{tabular}{|c|c|c|c|c|}
\hline Sources & $N S T$ & The Star & The Sun & Nation \\
\hline Government & 274 & 388 & 549 & 514 \\
\hline $\begin{array}{l}\text { World Health } \\
\text { Organisation } \\
\text { (WHO) }\end{array}$ & 6 & 34 & 0 & 1 \\
\hline Police & 34 & 48 & 82 & 66 \\
\hline Public & 69 & 50 & 352 & 156 \\
\hline Opposition & 4 & 5 & 129 & 73 \\
\hline
\end{tabular}

The result in Table III above shows that the dominant source of information for both the Malaysian and Nigerian newspapers is government source. It accounts for $72.6 \%$ in Malaysian newspapers and $55.3 \%$ in Nigerian newspapers. The second and third dominant sources in both countries are public and Police sources respectively. But in Malaysia, the fourth source is World Health organization (WHO), while in Nigeria, opposition source ranked fourth. Opposition source ranked fifth in Malaysia while World Health Organisation (WHO) ranked fifth in Nigeria.

Table IV shows the different types of news frames that featured in the Malaysian and Nigerian newspapers during the period of the crises. The table shows that New Straits Times used a total of 6 responsibility frame, representing $75 \%$ of total frame in Malaysian newspapers while the Star has a total of 2, which makes up $25 \%$. In conflict frame, NST has $8(42.1 \%)$, and the Star has $11(57.9 \%)$. This is followed by $3(33.3 \%)$ consequences frame from NST, and $6(66.7 \%)$ from the Star. In human frame, NST reported $3(42.1 \%)$ in number while the Star has 4 (57.1\%). Lastly, for moral frame, NST has $1(100 \%)$, while the Star has $0(0 \%)$.

TABLE IV: FRAMING IN THE MALAYSIAN AND NIGERIAN NEWSPAPERS

\begin{tabular}{lllll} 
Frames & NST & The Star & The sun & Nation \\
\hline Responsibility & 6 & 2 & 11 & 7 \\
Conflict & 8 & 11 & 16 & 10 \\
Consequence & 3 & 6 & 6 & 3 \\
Human & 3 & 4 & 6 & 8 \\
Moral & 1 & 0 & 8 & 7 \\
\hline
\end{tabular}

However, in order to determine the frame that featured more prominently, the number of times each frame was used by NST is added to the number of times it appeared in the Star. 
The result shows that conflict frame featured in the Malaysian newspapers more than others. It was used 19 times (43.2\%). The next is consequences frame which appeared 9 times, $(20.4 \%)$, followed by responsibility frame appearing 8 times, (18.2\%). Human frame occurred 7 times (15.9\%), and lastly moral frame was used 1 time, $(2.3 \%)$.

In the Nigerian newspapers, the findings show that the Sun used a total of 11 responsibility frame, $(61.1 \%)$ of total frame in Nigerian newspapers while the Nation has a total of 7 , $(38.9 \%)$. On the other hand, conflict frame appeared 16 times $(61.5 \%)$ in the Sun, and 10 times $(38.5 \%)$ in the Nation. Consequences frame appeared 6 times $(66.7 \%)$ in the Sun, and was used 3 times $(33.3 \%)$ in the Nation. Furthermore, human frame was used 6 times $(42.9 \%)$ in the Sun and 8 times $(57.1 \%)$ in the Nation. With regard to moral frame, the Sun recorded 8 (53.3\%) while the Nation has 7 (46.7\%).

This result shows that conflict frame featured more prominently in the Nigerian newspapers than other frames. Across the two newspapers, it featured 26 times, (31.8\%). This is followed by responsibility frame with a total 18 occurrences, $(21.9 \%)$. The third is moral frame, with a total of 15 occurrences, $(18.3 \%)$, followed by human frame with 14 appearances $(17.1 \%)$. The last is consequences frame which was used 9 times $(10.9 \%)$ of the total number of the frames used by the two newspapers.

\section{DISCUSSIONS}

A comparison of the aggregate coverage of the crises in the Malaysian and Nigerian newspapers shows that there is significant difference in the overall coverage of crises news in the two countries, $X^{2}(1, n=2,834)=359.951, P<0.001$. Nigerian newspapers have significantly reported more political, economic and environmental crises news than their Malaysian counterparts. On the other hand, Malaysian newspapers have significantly reported more health crisis than Nigerian newspapers.

The year 2007 was the height of Nigeria's political crisis in the current democratic political dispensation. As indicated in the study, the two Nigerian newspapers recorded a total of 456 political crisis stories in 2007, 219 in 2008, and 162 in 2009. Altogether, a total of 837 political crisis stories were reported. Nigeria witnessed a terrible political crisis in 2007, resulting from President Obasanjo's selfish ambition to change the country's constitution to enable him run for presidency the third time. This was against the constitutional provision of a presidential system of government in the country which allows for only two-term tenure for the office of the President. As expected, both the opposition parties and the Nigerian publics vehemently opposed this unconstitutional move, resulting to political turmoil. The aftermath of this was internal political crisis within the ruling Peoples' Democratic Party (PDP), which became divided over the move by the President. The crisis in the party boiled down to a battle between the President and his vice and strained the relationship between the two. Apart from this, the legislative (particularly the Senate) rose to the defense of the Nigerian constitution and the Nigerian people by rejecting in its entirety the idea of the President. At the expiration of the tenure of the two-term tenure of the
President in May 2007, Nigerians had hoped that there would be smooth transition of power from one civilian government to the other, but this never happened. The Vice President (Atiku Abubakar) who was supposed to have been the Presidential flag-bearer of the ruling party for the April 2007 polls was denied the ticket by the PDP at the dictate of the President (Obasanjo). Instead, the party handpicked Alhaji Musa Yar'Adua as the presidential flag-bearer and Dr. Goodluck Jonathan as his running mate. Following this drama, the Vice President, Atiku defected to the opposition party, All Nigerians Peoples" Party (ANPP), and became its presidential flag-bearer for the election. As envisaged, the April 2007 general election in Nigeria was claimed to have been marred by irregularities and rigging orchestrated by the ruling People's Democratic Party (PDP). For example, the Sun newspaper reported on $4^{\text {th }}$ February 2008 that the presidential poll result was written before the election day "Presidential polls: results in 29 states written before election - Buhari [12]. In this article, the presidential flagbearer of one of the opposition parties, Congress for Progressive Change (CPC), Muhammadu Buhari accused the ruling Peoples' Democratic Party and the Independent Electoral Commission (INEC) of mass rigging of the result.

He noted that the winner had already been predetermined by the ruling party. Notwithstanding, the candidate of the Ruling Peoples' Democratic Party, Alhaji Musa Yar'Adua was declared winner of the Presidential election. In contestation of the result, the opposition parties, especially the Presidential flagbearer of All Nigerian Peoples' party (ANPP), Alhaji Atiku Abubakar headed to the court to seek redress. Reference [13] captured the situation when it reported on $3^{\text {rd }}$ December 2007; "Presidential polls: Atiku goes to Supreme Court." He was not alone in this, as the Nigerian Labour Congress (NLC) joined many voices that flawed the polls, and on $12^{\text {th }}$ January 2008 called on the newly elected President to resign. Besides, the international community lent its voice in condemning the election. Reference [14] had earlier on $29^{\text {th }}$ April 2007, reported that 'Britain denounces general election." This political crisis lasted from April 2007 till December 2009, and left more to be desired of the political brass.

With regard to Malaysia, from the perspective of the two mainstream newspapers, the country did not experience any political crisis in 2007; hence the two papers have zero record on it. The reason is because of the perceived political stability in the country then, even though the general election the next year (2008) would consequently spark off political crisis. In 2008, a total of 30 political crisis stories were reported, resulting from the aftermath of the general election in which the ruling coalition, Barisan Nasional won slim majority in the parliament and lost five key states to the opposition This point marked the beginning of the build up for both internal and external political crisis that would ensue in the coming year. In 2009, there were a total of 239 political crisis stories. The bulk of the stories came from the Perak Assembly crisis which was a direct result of the outcome of 2008 election. Moreover, there were other stories from leadership crisis in Malaysian Chinese Association (MCA), the United Malay National Organisation (UMNO), and the Negri Sembilan Malaysian Indian Congress (MIC). In one of its reports on the 
crisis, the New Straits Times of $5^{\text {th }}$ February 2009 noted how Barisan Nasional claimed power from Pakatan Rakyat when three Independent members of Perak state Assembly defected to Barisan Nasional, causing the ruling opposition to lose majority in the house. Supported by the King of the state, Barisan Nasional took over power from Pakatan Rakyat, sacked the Menteri Besar and other house officials, leading to political crisis in the state which directly affected entire country. The paper further reported the reactions of Malaysian on this issue, particularly how Perak state youths protested against the new Barisan Nasional Government. Subsequently, on $20^{\text {th }}$ February 2009, the star report entitled "Battle of wills for Perak" portrayed a picture of political crisis in Perak state [15].

Though the economic crisis affected most countries in the world, yet it had more telling effects on those countries whose economies depend largely on the United States. Such countries include Nigeria whose economy is hinged on the export of crude oil to other countries, particularly, to the United States. There are other factors that resulted to the volume of reports on economic crisis in Nigeria from the period 2007 to 2009. They included Government's increase of pump price of petrol to seventy-five (N75) naira, and also the failed banks cases. The manner in which the Nigerian government raised the pump price of petrol caused disaffection and consequently led to protests and strikes by Nigerians championed by the Labour Unions. On $2^{\text {nd }}$ June 2007, the sun reported how the Nigerian Labour Congress gave the government 14-day ultimatum to rescind its decision on petrol price or face the consequences. The global economic recession equally hit Malaysia, but not as much as Nigeria. On October 26, 2008, the New Straits times reported the urgency with which the Prime Minister, Abdullah Badawi was tackling the crisis. The paper revealed government's efforts to provide jobs for those who lost theirs as a result of the crisis. While the two Nigerian newspapers focused more on the consequences of the crisis, Malaysian newspapers paid more attention to government's efforts to contain the crisis.

One of the major differences between Malaysian and Nigerian newspapers in this study is health crisis. As stated earlier, Malaysian newspapers reported more health crisis news than Nigerian newspapers. Does this mean that Malaysian experiences more health crisis than Nigeria? One of the reasons for this is the outbreak of the dengue fever, and A (H1N1) in country from 2007 to 2009. Evidence of this abounds in the reports from the two newspapers. The New Straits Times coverage of the health crisis stretched from 2007 to 2009. The massive coverage given to this crisis by Malaysian newspapers is a reflection of how much the mainstream newspapers focus on improving the quality of life of the people by the government, projecting the government as the one that cares much about her citizens. The newspapers were used as agent ofsensitization and education of members of the public on the dangers posed by these diseases. Through straight news, editorials, features and adverts, the papers were able to keep the public informed of what was happening.

In Nigeria, bird flu crisis did not feature prominently compared to Malaysia, even though it occurred in a few places. Rather, the country experienced the outbreak of
"Lassa fever" - an acute viral hemorrhagic fever caused by the Lassa virus. However, it is interesting to note that more attention was paid to the personal health crisis of the then Nigerian President, Alhaji Musa Yar'Adua. His health condition turned out to be an issue of national attention and concern between 2008 and 2009. The newspapers started writing about this when he started seeking medical treatments overseas. Reference to [16], on $26^{\text {th }}$ August 2008, the Sun wrote "Much Ado about Yar'Adua's health", commenting on the confusion that trailed the different versions of the state of the President's health. Earlier on, the Nation had on $15^{\text {th }}$ April 2008 reported "Yar'Adua in Germany for medical check-up". Events turned out to crisis level when he eventually travelled to Saudi Arabia for medical treatment in November 2009 without notifying the National Assembly or handing power over to the Vice President [17]. His absence threw the entire country into confusion. The political and constitutional dramas that followed this created more division in the polity; hence it is ironical that the personal health of the President became a national health crisis.

Besides, the Nigerian environmental landscape is characterized with pollution, particularly in the Niger Delta region of the country. The region contains the largest oil reserves in Sub-Saharan Africa, with an estimated 40 billion barrels. Shell began oil pumping there in 1950, when Nigeria was still part of British Empire. Today its subsidiary the Shell Development Corporation Company of Nigeria extracts some 100 million barrels a year, in a joint venture with the state owned Nigeria National Petroleum Company (NNPC). Sadly enough, over the past half century, oil companies have turned the Niger delta in West Africa, one of the world's largest mangrove swamps, into a poisoned landscape. In his report in the online magazine 'Yale Environment 360: Opinion, Analysis, Reporting and Debate' published on $16^{\text {th }}$ April 2012, an environmental writer/consultant, Fred Pearce noted, One estimate is that 1.5 million tons of oil has been spilled into the wetlands over the decades from the delta's 5,000 oil wells and more than 5,000 kilometers of pipelines. And with all this happening amidst some 1,500 delta villages, where ten million fishermen and farmers gain little from the vast wealth being created around them, it has also been a recipe for injustice and conflict [18].

This neglect on the part of government and Shell Corporation forced youths in the region to take arms against the government and oil companies demanding for their rights. The Sun newspaper in its edition of $1^{\text {st }}$ July 2009 projected the Niger Delta environmental crisis as a human tragedy, and accused the multinational oil corporations of sharp practices in handling the situation. It also reported how the court in its damage ruling mandated Shell to foot environmental clean-up bill in Ogoni, Rivers State. But in Malaysia, most of the environmental reports were from flooding and landslides. There were floods in some parts of the country, particularly in the states of Johor, Malacca, Terrenganu, Pahang and Kelantan.

\section{NEWS SOURCES}

The dominance of government sources in Malaysia is because media ownership pattern in the country is one where 
government, or individuals and groups who have close link to the ruling government own and control the media, including newspapers. Reference [19] noted that the history of the mainstream press and broadcasting in Malaysia has been one of stringent political, legal and, more recently, economic controls. According to them, under this situation, journalists in the country depend on government source to gather information to write news. In corroboration of this fact, Rashid, the Associate Editor of NST, in an interview session acknowledged that during crisis, background reporting is crucial to what their reporters do and as such official information will have to be gazette from the government because they are the people in-charge [20]. Again, his counterpart from the star noted that there are not many reliable sources of information in the country when crisis occur, except the government. This can also be related to Brian's findings that spot news and information subsidies such as news releases and officials' statements to the media are among the hallmark features of passive newsgathering among Southeast-Asian countries [21].

In the same vein, newspapers in Nigeria are owned by the governments, individuals and groups close to the corridors of power. For example, both the Sun newspaper and the Nation are owned by two former state governors, closely linked to their different political affiliations. There is no doubt that journalists in these two papers turned to government sources for information. The idea is that this will help them to run away from publishing stories that could anger the government and bring trouble to the company. In his words, Obiora, of the editorial board of the Sun newspaper agreed that it is natural to go with the flow of the news if it is from government [22]. He questioned if there is anything wrong with relying on government sources, and pointed out that the four types of crisis under study are all managed by the government whenever they occur in any country; hence it is government sources that are most reliable under this circumstance.

These findings support Netto' argument that newspapers in developing countries have the tendency to use sources that appear to be credible or to lend credibility to the messages contained in their reports [23]. The higher the seat a person occupies in the hierarchy of authority, the higher his perceived credibility as a source of that news. In this sense, newspapers are inclined to obtain information from authoritative sources, as they are the decision-makers in the society and possess the necessary resources to implement the decision regarding development projects. In Malaysia in particular, both the New Straits Times and the Star relied heavily on government sources, giving little voice to the opposition parties. The papers allowed the ruling party to act as opinion leader, particularly in defining the Perak State political crisis. Reference [24] noted that there is a strong and yet unhealthy tendency in Malaysia to view oppositionism negatively, both by academics and non-academics. This according to him has led to the government and individuals being intolerant to criticism, including healthy ones. He remarked that some even see oppositionism as something negative and bad for national unity and integration. The Editors of the four newspapers acknowledged that during crisis, conflicting interests may arise as journalists pursue to tell everything while the government seeks to control the public from panicking. One way Nigerian newspapers differ in their handling of news from opposition is that there are many newspapers in the country that can voice out opposing viewpoints. Again, the two Nigerian newspapers (the Sun and the Nation) sometimes highlight positive issues about the opposition, particularly in recent times when their owners have switched over to opposition camp.

\section{NEWS FRAMES}

To interpret how Malaysian and Nigerian newspapers constructed the 2007 to 2009 political, economic, health and environmental crises requires an understanding of the news process. Reference [25] observed that news as the construction of reality is a complex process which begins with a systematic sorting and selecting of events and topics according to a socially constructed set of categories. According to Reese, these sets of socially constructed categories are frames, the organizing ideas in news which define the meaning of the news texts [26].

The two Malaysian newspapers used conflict frame in the presentation of the political crisis in the country. Reference [27] had on $4^{\text {th }}$ February 2009 reported "Deeper into crisis, what now?" The following day, $5^{\text {th }}$ February 2009, the paper also reported, "Perak government in limbo: Barisan Nasional claims power, 3 independents declare support for $B N^{\prime \prime}$ [28]. Subsequently, on $9^{\text {th }}$ February 2009, the paper also reported that "Youths protest against new Barisan Nasional Government in Perak" [29]. These three news reports depict a situation of conflict, and the headlines were presented in a manner that suggests that the opposition was the one fomenting trouble in the Perak State Assembly. In the Star newspaper, attention was more on the intra-party crisis in the Malaysian Chinese Association (MCA). The Star's reports portray a picture of a factionalized MCA, one supporting the then President of the party, Tee Keat Ong, and another faction supporting the Vice President, Datuk Seri Liow Tiong Lai. On $14^{\text {th }}$ October 2009 , the paper reported how the faction that was supporting Tee Keat Ong urged him not to resign as demanded by other members of the party, "Don't resign, Tee Keat urged" [30], with another headline stating "Lee: more chaos if Ong goes."

In Nigeria, the papers also used conflict frames to report the political crisis in the country during the time. The Sun captured the crisis when on $3^{\text {rd }}$ December 2007, Atiku Abubakar, the Presidential flagbearer of the All Nigerian Peoples' Party (ANPP) headed to the court to contest the result of the election. Reference [31] also reported on $12^{\text {th }}$ January 2008 how the Nigerian Labour Congress (NLC) called on the President to resign; "Flawed polls: Labour calls for Yar'Adua's resignation." The same day the Nation carried a story expressing President Yar'Adua's worries over the election tribunal cases; 'Yar'Adua worried over tribunal cases" [32]. On his part, Atiku Abubakar on 22 ${ }^{\text {nd }}$ January 2008 prayed the tribunal to nullify the election; "Atiku urges tribunal to cancel election" [33]. This political crisis lasted from April 2007 till December 2009 and shows the enormity of the issue. 
On economic crisis, the Malaysian newspapers employed different news frames in reporting the news stories. The New Straits Times used responsibility frame to show government's commitments to cushion the effects of the economic crisis and abet people's sufferings. Reference [34] on 26th October 2008 under the headline "Abdullah tackles global food crisis with urgency "reported the urgency at which the Prime Minister, Abdullah Badawi tackles the crisis On $21^{\text {st }}$ January 2009, and $16^{\text {th }}$ February 2009, under the headlines "jobs for the jobless within a month" [35] and "Good news for the retrenched: 20,000 jobs in civil service" [36] respectively, the paper also reported on government's efforts to provide new jobs for those who were laid off because of the crisis. However, the star newspaper adopted a different frame in reporting the stories. It instead focused more on the consequences of the economic crisis to the nation by using consequences frame in some of its news stories. Reference [37] of $30^{\text {th }}$ July 2007 with the headline, "Financial volatility ahead" peeped into the future of the country's financial system. The paper also observed with sadness the increase in the price of rice which is Malaysia's main staple food, "Price of rice on the rise" [38]. The paper equally paid attention to the comments from economic experts when it reported on $20^{\text {th }}$ January that "Economic crisis can kill, says expert" [39].

Reporting the economic crisis in Nigerian the Sun used different news frames. On $2^{\text {nd }}$ June 2007 the paper used conflict frame when it reported that "Labour gives 14 day ultimatum over fuel price hike" [40]. The paper highlighted how the Nigerian Labour Congress mobilized the masses against the federal government because of increase in the pump price of petrol. Reference [41] used consequences frame to portray the sufferings of the masses when it reported that "Passengers stranded nationwide as aviation fuel scarcity persists" Besides, the Sun presented some of the economic crisis stories by using responsibility frame. For example the paper reported on $5^{\text {th }}$ April 2008 that "President Yar'Adua moves to halt fuel scarcity" [42]. Subsequently, on $17^{\text {th }}$ April 2008, the paper highlighted how the government questioned the Minister of Agriculture over the food crisis. The headline of the story reads, "House of Representatives summons Agric Minister over food crisis" [43] The Nation newspaper captured the crisis through responsibility and consequences frames. For example, the paper's news story on $10^{\text {th }}$ October 2008 portrays Nigeria's government showing concern for the economy; hence it stated "Yar'Adua rallies private sector against global crisis" [44]. On the other hand, the paper expressed the consequences of the crisis on the country when it reported on $22^{\text {nd }}$ October 2008 that "Nigeria weighs pains of global financial crisis" [45]

In reporting health crisis, the two Malaysian newspapers used a combination of consequences, responsibility and moral frames in presenting their news. Reference [46] had on $14^{\text {th }}$ June 2007 raised alarm on impending danger of a possible pandemic on dengue fever when it reported that "7million people at risk if pandemic hits." The same applies to its report on $7^{\text {th }}$ July 2009 which reads, "Dengue epidemic and it will get worse" [47]. The two reports focused on the consequences of the dengue on the people. On the other hand, reporting on government's effort through the Ministry of
Health, the paper used responsibility frame to report on $31^{\text {st }}$ December 2008 that, "Pig farm quarantined" [48]. The paper projected this as one of the many measures the government has taken to overcome the twin health crisis of dengue fever and A (H1N1). Besides, the Star newspaper also gave an in-depth coverage of the crisis. Reference [49] of $3^{\text {rd }}$ January 2009 captured the scenario in the following news report "108 dengue deaths last year." This article assessed dengue cases in the country in 2008, and lamented how the crisis claimed many lives. Reference [50] also under the headline "Dengue cases on the rise in Perak" highlighted on the menace of the disease in the state of Perak. In view of this revelation, the Malaysian government intensified efforts to fight against the disease, as subsequently reported in the paper on $28^{\text {th }}$ January 2009 "Anti-dengue campaign intensified" [51]. Again, reference [52] also reported that the Kuala Lumpur City Council was to intensify the fight against dengue fever; "DBKL to step up war on dengue." On A (H1N1), the Star used human frame to re-enact government's resolve to protect the people against falling victims of the disease. Reference [53] report on $28^{\text {th }}$ April 2009 wrote on how government warned the people to avoid going to places that have been hit by the flu; "Government: Avoid going to flu-hit areas". Nevertheless, some of the stories were written in such a way that they caused panic among the people. For example, on $13^{\text {th }}$ May 2009, the Star reported that 38 victims have been admitted to the hospital, and on $4^{\text {th }}$ August 2009, it remarked that death toll has risen to 8, with 569 new A (H1N1) cases [54].

During the same period in Nigeria, the Sun newspaper reported the seriousness of the health condition of President Yar'Adua by using the word 'critical'; 'Yar'Adua's health critical" [55]. By using human frame, the paper reported how on $1^{\text {st }}$ December 2009 the Senate President, David Mark called on Nigerians to embark on a 9 day special prayers for the ailing President - "Yar'Adua: Mark calls for 9 day special prayers" [56]. His call came after many speculations about the health condition of the President. On its own, the Nation equally employed human frame and conflict frame to present the news. Reference [57] of $27^{\text {th }}$ December 2009 also reported Yar'Adua's health: New Year may begin without head of executive, judiciary" This report was an aftermath of political intrigues that enveloped the absence of the President who left the country with transferring power to either to the Vice President or the Senate President.

In their coverage of environmental crisis, the New Straits Times focused more on government's efforts to help the affected people, while the Star concentrated on the losses incurred as a result of the flood. The New Straits Times used responsibility frame to project government's efforts to curb the menace when it reported on $10^{\text {th }}$ January 2007 that; "Urgent aid needed for flood victims" [58] Reference [59] also stated that "Flood losses RM100M: Government announces fresh aids for families." On the other hand, the star used consequences frame to bring to the fore, the various losses incurred by the victims of the flood. Reference [60] of $23^{\text {rd }}$ January 2007, reported how flood washed away RM500M in Johor, and also on $8^{\text {th }}$ January 2008, it highlighted how RM50 million was lost as a result of the flood [61]. 
On their part, Nigerian newspapers employed both conflict and consequences frames to present the news. Reference [62] reported in such a tone that suggests that the militants were the ones dictating for the President. The report reads; "Niger Delta militants set agenda for Yar'Adua". This headline depicts a situation of chaos and goes a long way to evoke tension in the Nigerian polity. Again, on $14^{\text {th }}$ June, 2007, the paper reported that Nigeria would be in trouble if the Niger Delta conference fails [63]. In its headline, the paper wrote; "Nigeria in trouble if Niger Delta conference fails." Also, the paper used conflict frame to paint a picture of a rebellious people confronting the government. On the other hand, the Nation newspaper focused more on the consequences of the crisis. In its many news reports on the issue, the paper explored many of the protests by the angry Niger Delta youths and highlighted the implications of the situation on Nigerian economy. On $18^{\text {th }}$ February 2008; it reported that oil companies have declined to return to Niger Delta [64]. This report came as a result of alleged continuous harassment and kidnapping of oil workers, which created a situation of fear and hostility in the workers, especially foreign nationals. Apart from this, the paper equally reported the appeal by the Nigeria's President for people of the region to embrace dialogue as a means of peaceful resolution to the crisis.

\section{CONCLUSION}

This study has shown how newspapers in the two countries differ in their reporting of the crises. On a specific note, the fact that the two Nigerian newspapers focused more on political crisis does not mean that the percentage of crisis reports in other areas is a true reflection of what is obtainable on ground. Rather, it is a reflection of how politics dominates other aspects of live in the Nigerian society. This stems from the inability of government to peacefully transfer power from one democratic government to the other. As noted by Adebanwi, historically, the Nigerian press has been a site of contest for many conflicts in the country, and this constantly reflects the tensions inherent in the plural nature of the Nigerian society [65].

In the same vein, the domination of health crisis news in Malaysian newspapers does not mean that everything is fine with Malaysian politics. The country's political environment is considered as a very sensitive issue, so journalists are required to apply caution in reporting about it. Again, they are expected to work as partners of government in the development efforts of the country rather than focusing attention on crisis reporting. Reference [66] remarked that the media system in Malaysia is an important agent of socio-political, economic and cultural change. Also, she observed that considering the fact that its power, influence and impact have no limits, may disrupt and destabilize the society if wrongly managed.

This finding is consistent with the arguments of Skjerdal and Wong when they implied in their research that journalists of countries that practice Development Journalism are required to evaluate their country's leader's speech in positive light [67].

With regard to framing, it is good to say that by focusing attention on one or two crises rather than others the four newspapers have reported the crises in the frames they like. By choosing what to report and what not to report, the journalists in the four newspapers were able to direct the attention of the public to what the media want them to know. Besides, it is important to note that throughout the duration of the crises, the Malaysian and Nigerian publics depended on newspapers for in-depth news about the situations. This is mainly because whenever there is crisis, though people will switch on their television sets, turn on their radio, yet they will usually pick a copy of newspaper for detailed reports about the crisis. In a way, it supports the idea that freedom of expression and information is essential at any time in a democratic society but it becomes all the more important in times of crisis.

These findings support the hypothesis which states that newspapers in the two countries have differed in their reporting of the crises.

At this point, it is pertinent to suggest that further studies be taken in this area of research by focusing on the Malaysian and Nigerian publics, especially regarding their perception towards newspapers role in crisis reporting. This is because the current study focuses more on newspapers and the journalists. Such studies will help to deepen one's understanding of the differences and similarities in the two countries.

\section{REFERENCES}

[1] R. C. Chandler, J. D Wallace, and F. Scott, Six Points for improving Crisis Communication Plans: The Application of Visual Communication for Effective Crisis Response, A white paper by Tanberg, pp. 3, March 2007.

[2] A. D. Scheufele and D. Tewksbury, "Framing, agenda-setting, and priming: The evolution of three media effects models," Journal of Communication, vol. 57, no. 1, pp. 9-20. Sept. 2007.

[3] D. Weaver, "Thoughts on agenda-setting, framing, and priming," Journal of Communication, vol. 57, no. 1, pp. 142-147. Feb. 2007.

[4] V. B. Gorp, "The constructionist approach to framing: Bringing culture back in," Journal of Communication, vol. 57, no. 1, pp. 60-78, March 2007.

[5] J. W. Tankard, "Framing Public Life: Perspectives on Media and Our Understanding of the Social World," in The Empirical Approach to the Study of Media Framing, S. D. Reese, O. H. Gandy, A. E. Grant (eds) New Jersey: Lawrence Erlbaum Associates, 2008, pp. 95-105

[6] J. Bryant and D. Miron, "Theory and research in mass communication," Journal of Communication, vol. 54, no. 4, pp. 662-704, Dec. 2004.

[7] R. M. Entman, "Framing Bias: Media in the distribution of power," Journal of Communication, vol. 57, no. 1, pp. 163-173, Feb. 2007.

[8] O. R. Holsti, Content Analysis for the Social Sciences and Humanities, Don Mills: Addison-Wesley Publishing Company. 1969, p.116.

[9] D. Riffe, S. Lacy, and F. Fico, Analyzing Media Messages: Using Quantitative Content Analysis in Research, New Jersey: Lawrence Erlbaum Associates, July 2005, pp. 70-95

[10] H. A. Semetko and P. M. Valkenburg, "Framing European politics: A content analysis of press and television news," Journal of Communication, vol. 50, no. 2, pp. 93-109, 2000.

[11] R. Neuman, M. Just, and A. N. Crigler, Common Knowledge: News and the Construction of Political Meaning (American Politics and Political Economy Series), Chicago: University of Chicago Press, pp. 7-22, October 1992.

[12] The Sun newspaper, "Presidential polls: Results in 29 states written before election - Buhari,” pp. 7, Feb. 4, 2008.

[13] The Sun newspaper, "Presidential polls: Atiku goes to Supreme Court," pp. 6, Dec. 3, 2007.

[14] Nation newspaper, "Britain denounces general election," pp. 8 April 29, 2007.

[15] The Star newspaper, "Battle of wills for Perak," pp. 23, February 2009.

[16] The Sun newspaper, "Much ado about Yar'Adua's health," pp. 23, 26-27, August 26, 2008.

[17] Nation newspaper, "Yar' Adua in Germany for medical check-up," pp. 4, 2008, April 15. 
[18] F. Pearce. (April 2012) on Hopes fade for cleanup in Nigeria's oil-rich Delta. Yale Environment 360: Opinion, Analysis, Reporting and Debate. [Online]. Available: http://e360.yale.edu/feature/hopes_fade_for_cleanup_in_nigerias_oilrich_delta/2517/

[19] Z. Nain and M. Anuar, "Ownership and control of the Malaysian media," Media Development, vol.14, no. 4, pp.9-17, April 1998.

[20] Y. Rashid, Crisis Reporting in the New Straits times newspaper, Interview session in September 2012.

[21] B. L. Massey, "How three Southeast-Asian newspapers framed the haze of 1997-98," Asian Journal of Communication, vol. 10, no. 1, 72-94, May 2009.

[22] R. Obioha, Crisis Reporting in the Sun newspaper, Interview session in October 2012.

[23] A. Netto, "Media freedom in Malaysia: The challenge facing civil society," Media Asia, vol. 29, no. 1, pp. 17-23, 2002.

[24] A. B. Shamsul, "Identity contestation in Malaysia: a comparative commentary on 'Malayness' and 'Chineseness'," Akademika, vol. 55, July 1999.

[25] S. Hall. "Social production of news," in Policing the Crisis: Mugging, the Stage, and Law and Order, S. C. Critcher, T. Jefferson, J. Clarke, and B. Roberts (Eds.), Hall et al., London: Macmillan. 1978.

[26] S. D. Reese, "Framing public life: A bridging model for media research," in Framing Public Life: Perspectives on Media and our Understanding of the Social World, NJ: Lawrence Erlbaum Associates. July 2001, pp.60-76

[27] New Straits Times newspaper, "Deeper into crisis, what now?" pp. 4, 6-7, February 2, 2009.

[28] New Straits Times newspaper, "Perak Government in limbo: Barisan Nasional claims power, 3 independents declare support for BN," February 5, 2009.

[29] New Straits Times newspaper, "Youths protest against new Barisan Nasional government," pp. 4, February 9, 2009.

[30] The Star newspaper, "Don’t resign: Tee Keat urged,” pp. 4, October 14, 2009.

[31] The Sun newspaper, "Flawed polls; Labour calls for Yar' Adua's resignation," pp. 7, January 14, 2008.

[32] The Nation newspaper, Yar' Adua worried over tribunal cases," pp. 8, January 12, 2009.

[33] The Nation newspaper, "Atiku urges tribunal to cancel election," pp. 4, January 22, 2009.

[34] New Straits Times newspaper, "Abdullah tackles global financial crisis with urgency," pp. 2, October 26, 2008.

[35] New Straits Times newspaper, "Jobs for the jobless within a month," pp 6-8, January 24, 2009.

[36] New Straits Times newspaper, "Good news for the retrenched: 2000 jobs in the civil service," pp. 1-8, February 16, 2009.

[37] The Star newspaper, "Financial volatility ahead," pp. 46, July 30, 2007.

[38] The Star newspaper, "Price of rice on the rise," pp. 21, April 13, 2008.

[39] The Star newspaper, "Economic crisis can kill: Says expert," pp. 42, January 20, 2009.

[40] The Sun newspaper, "Labour gives 14 days ultimatum over fuel price hike," pp. 10, June 2, 2007.

[41] The Sun newspaper, "Passengers stranded nationwide as aviation fuel scarcity persists," pp. 4, February 8, 2008.

[42] The Sun newspaper, "President Yar'Adua moves to halt fuel scarcity," pp. 11, April 5, 2008.

[43] The Sun newspaper, "House of Rep summons Agric Minister over food crisis," pp. 6, April 17, 2008.

[44] The Nation newspaper, "Yar'Adua rallies private sector against global crisis," pp. 2, October 10, 2008.

[45] The Nation newspaper, "Nigeria weighs pains of global financial crisis," pp. 2, October 22, 2008.
[46] New Straits Times newspaper, "7 million people at risk if pandemic hits," pp. 18, June 14, 2007.

[47] New Straits Times newspaper, "Dengue epidemic and it will get worse," pp. 4, July 7, 2007.

[48] New Straits Times newspaper, "Pig farm quarantined," pp. 19 December 31, 2008

[49] The Star newspaper, "108 dengue deaths last year,” pp. 31, January 3, 2009.

[50] The Star newspaper, "Dengue cases on the rise," pp. 27, January 24, 2009

[51] The Star newspaper, "Anti-dengue campaign intensifies," pp. 17, January 28, 2009.

[52] The Star newspaper, "DBKL to step up war on dengue," pp. 2, February 4, 2009.

[53] The Star newspaper, "Government: Avoid going to flu hit areas," pp. 6 , April 28, 2009.

[54] The Star newspaper, "569 new A (H1N1) cases," pp. 14, August 21, 2009.

[55] The Sun newspaper, "Yar'Adua's health critical," pp. 52, August 31, 2008.

[56] The Nation newspaper, "Yar'Adua: Mark calls for 9 day special prayers," pp. 6, December 1, 2009.

[57] The Nation newspaper, Yar'Adua's health: New year may begin without head of executive, judiciary," pp. 8, December 27, 2009.

[58] New Straits Times newspaper, "Urgent aid needed for flood victims," pp. 6- 8, January 8, 2007.

[59] New Straits Times newspaper, "Flood losses Rm100m; Govt. announce fresh aids for families," pp. 6-8, January 12, 2009.

[60] The Star newspaper, "Floods wash away Rm500 million in Johor," pp. 49, January 23, 2007.

[61] The Star newspaper, "Rm50 million gone during floods," pp.15, January 8, 2008.

[62] The Sun newspaper, "Niger Delta militants set agenda for Yar' Adua," pp. 7, May 25, 2007.

[63] The Sun newspaper, "Nigeria in trouble if Niger Delta conference fails," June 14, 2007.

[64] The Nation newspaper, "Oil companies decline to return to Niger delta," pp. 8, February 10, 2008.

[65] W. Adebanwi, in the National Question in Nigeria: Comparative Perspectives, Abubakar Momoh and Said Adejumobi (eds.), The Nigerian Press and the National Question, Hampshire, England: Ashgate, 2002, pp. 201-215.

[66] H. Azizah, “'Malaysia's role in National Development: Media Policy and National Stability," Malaysian Journal of Media Studies, vol. 11, no. 1 , pp. 49-58, 2009

[67] T. Skjerdal and Wong, "Development Journalism Revived: the case of Ethiopia," Ecquid Novi: African Journalism Studies, vol. 32, no. 2, pp. 58-74, July 2011.

Ihediwa Samuel Chibundu was born in Imo state, Nigeria. He obtained higher national diploma in mass communication of the Institute of Management and Technology (IMT), Enugu 1997 and a postgraduate diploma in Public Administration of the University of Nigeria (UNN) Nsukka, 2002. In 2007, he earned a master of arts degree in Media studies of the University of Malaya, Kuala Lumpur, Malaysia. Before coming to Malaysia in 2004, Mr. Ihediwa has worked as a journalist with the Rivers State Broadcasting Corporation (RSBC), and also with the Service Newspaper, both in Port Harcourt, Nigeria. He joined the Universiti Tunku Abdul Rahman (UTAR) as a teaching staff in August 2009 and has been there till date. He is currently pursuing his Ph.D. in Media studies at the University of Malaya, Kuala Lumpur, Malaysia.

His research interests are crisis reporting, citizen journalism and investigative reporting among others. 